\title{
In Situ Enhanced Soil Mixing
}

\section{INNOVATIVE TECHNOLOGY SUMMARY REPORT}

\section{demonstrated at}

U.S. Department of Energy

X-231B

Portsmouth Gaseous Diffusion Plant

Piketon, $\mathrm{OH}$

\section{prepared for}

\section{U.S. Department of Energy}

Office of Environmental Management

Office of Science and Technology

February 1996 


\section{DISCLAIMER}

This report was prepared as an account of work sponsored by an agency of the United States Govemment. Neither the United States Government nor any agency thereof, nor any of their employees, makes any warranty, express or implied, or assumes any legal liability or responsibility for the accuracy, completeness, or usefulness of any information, apparatus, product, or process disclosed, or represents that its use would not infringe privately owned rights. Reference herein to any specific commercial product, process, or service by trade name, trademark, manufacturer, or otherwise does not necessarily constitute or imply its endorsement, recommendations, or favoring by the United States Government or any agency thereof. The views and opinions of authors expressed herein do not necessarily state or reflect those of the United States Govemment or any agency thereof.

This report has been reproduced directly from the best available copy.

Available to DOE and DOE Contractors from the Office of Scientific and Technical Information, P.O. Box 62, Oak Ridge, TN 37831; prices available from (615) 576-8401.

Available to the public from: The Center for Environmental Management Information, P.O. Box 23769, Washington, DC 20026-3769 (1-800) 736-3282 .

or

The U.S. Department of Commerce, Technology Administration, National Technical Information Services, Springfield, VA 22161 (703) 487-4650. 


\section{In Situ Enhanced Soil Mixing}

\section{INNOVATIVE TECHNOLOGY SUMMARY REPORT}

\section{demonstrated at}

\section{U.S. Department of Energy}

$\mathrm{X}-231 \mathrm{~B}$

Portsmouth Gaseous Diffusion Plant

Piketon, $\mathrm{OH}$

\section{prepared for}

U.S. Department of Energy

Office of Environmental Management

Office of Science and Technology

February 1996 


\section{DISCLAIMER}

Portions of this document may be illegible in electronic image products. Images are produced from the best available original document. 


\section{TABLE OF CONTENTS}

1 SUMMARY

page 1

2 TECHNOLOGY DESCRIPTION

page 4

3 PERFORMANCE

page 6

4 TECHNOLOGY APPLICABILITY \& ALTERNATIVES

page 11

5 Cost

page 12

6 REGULATORY/POLICY ISSUES

page 14

7 LESSONS LEARNED

page 15

\section{APPENDICES}

A Demonstration Site Characteristics

B Technology Description/Performance Detail

C Technology Selection Detail

D References 


\section{SUMMARY}

\section{Technology Description}

In Situ Enhanced Soil Mixing (ISESM) is a treatment technology that has been demonstrated and deployed to remediate soils contaminated with volatile organic compounds (VOCs). The technology has been developed by industry and has been demonstrated with the assistance of the U.S. Department of Energy's Office of Science and Technology and the Office of Environmental Restoration.

- ISESM encompasses a number of in situ soil treatment technologies that can treat contaminated soils, especially those of a fine-grained nature, which are difficult to treat with other remediation technologies. Contaminants are either removed from the soils or stabilized in place. The mixing process allows good access for reagent delivery to all soil particles and the interstices between particles. The technology is particularly suited to shallow applications, above the water table, but can be used at greater depths.

- ISESM technologies demonstrated for this project include:

$\checkmark$ soil mixing with vapor extraction combined with ambient air injection [Contaminated soil is mixed with ambient air to vaporize volatile organic compounds (VOCs). The mixing auger is moved up and down to assist in removal of contaminated vapors. The vapors are collected in a shroud covering the treatment area and run through a treatment unit containing a carbon filter or a catalytic oxidation unit with a wet scrubber system and a high efficiency particulate air (HEPA) filter.]

$\diamond$ soil mixing with vapor extraction combined with hot air injection [This process is the same as the ambient air injection except that hot air or steam is injected.]

$\checkmark$ soil mixing with hydrogen peroxide injection [Contaminated soil is mixed with ambient air that contains a mist of diluted hydrogen peroxide $\left(\mathrm{H}_{2} \mathrm{O}_{2}\right)$ solution. The $\mathrm{H}_{2} \mathrm{O}_{2}$ solution chemically oxidizes the VOCs to carbon dioxide $\left(\mathrm{CO}_{2}\right)$ and water.]

$\checkmark$ soil mixing with grout injection for solidification/stabilization [Contaminated soil is mixed as a cement grout is injected under pressure to solidify and immobilize the contaminated soil in a concrete-like form.]

- The soils are mixed with a single-blade auger or with a combination of augers ranging in diameter from 3 to 12 feet. Mixing is likely to be effectively applied to depths of $40 \mathrm{feet}$, although commercial vendors have worked at depths as great as 100 feet with the smaller diameter augers. Enhancements such as injection of heated air in combination with vapor extraction, injection of oxidants, or injection of grout are utilized based on the specific system selected for a particular site.

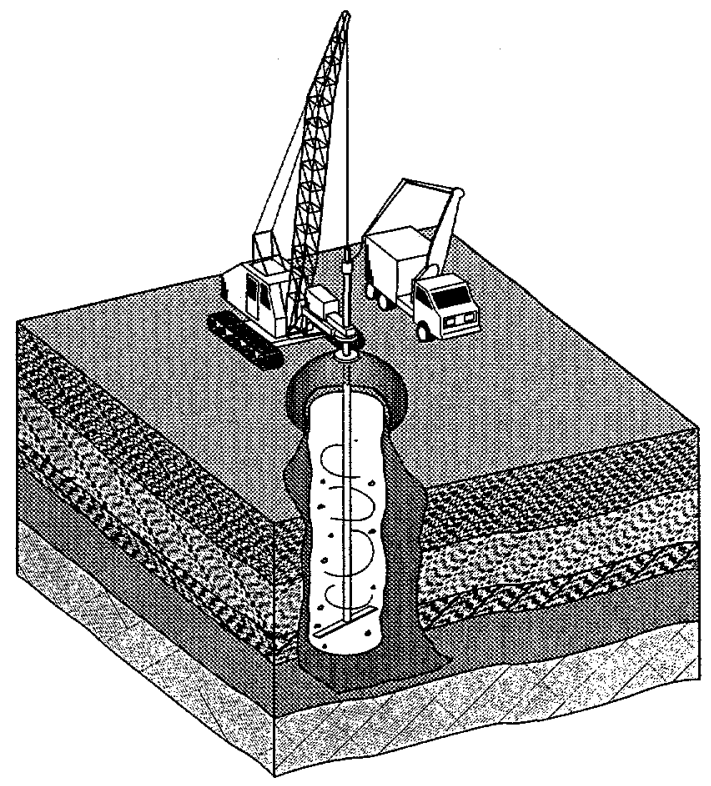

Illustration of the continuously mixed subsurface soil reactor concept. (Note: treatment agents are delivered through the mixing blade with emissions captured in the shroud covering the mixed region.) Rigs can have single or multiple shafts. 


\section{Technology Status}

- In situ soil mixing, also known as deep soil mixing, shallow soil mixing, soil mixing wall, auger mixing, etc., has been used for a number of years in the construction industry. Cement grout is typically mixed with soil to create a foundation system or barrier wall. Soil mixing with stabilization (Geo-Con/IWT) was demonstrated under the EPA SITE Program in 1990 at a General Electric Shop in Hialeah Florida where soils were contaminated with PCB's.

- The above four ISESM treatment technologies were selected for evaluation during a full-scale field demonstration at the Department of Energy (DOE) Portsmouth Gaseous Diffusion Plant (PGDP), near Piketon Ohio. The field demonstration was conducted at the X-231B Unit in June 1992. Replicated tests of in situ vapor stripping, peroxidation, and solidification were made in soil columns measuring $10 \mathrm{ft}$ in diameter and $15-22 \mathrm{ft}$ deep.

- The X-231B Unit was used from 1976 to 1983 as a land disposal site for waste oils and solvents. Soils beneath the unit were contaminated with VOCs, such as TCE at approximately 100 parts per million (ppm), and low levels of radioactive substances. The shallow ground water (12-14 ft depth) was also contaminated, and some contaminants were above drinking water standards. Approximately $78 \%$ of the VOCs were located in the upper $12 \mathrm{ft}$.

- Geologically the site contains low permeability sediments, composed of silt and clay deposits with hydraulic conductivities of less than one millionth of a centimeter per second $\left(\mathrm{K}<10^{-6} \mathrm{~cm} / \mathrm{s}\right)$.

- A computerized data acquisition system linked to approximately 60 sensors enabled near-continuous monitoring of process operation and performance. Nearly 500 soil and gas samples were collected before, during, and after soil treatment for analyses of physical, chemical, and biological parameters. Soil matrix, soil vapor, and off-gas VOC measurements were made.

- The technology demonstration was a public/private partnership effort between Oak Ridge National Laboratory (six divisions), DOE-Portsmouth Field Office, Lockheed Martin Energy Systems at Portsmouth, University of Tennessee, Michigan Technological University, Chemical Waste Management, Millgard Environmental Corporation, Envirosurv, and NovaTerra.

- After the demonstrations were completed, the most effective of the four technologies, thermal vapor extraction, was selected as the remedial option for the site. Cleanup and closure of the site was completed in 1994. This innovative treatment technology resulted in a total cost savings of $\$ 80$ million as compared to traditional excavation and treatment approaches. Closure activities were completed by Geo-Con.

- A number of companies provide ISESM technology commercially(see U.S. EPA VISITT database and DOE Commercial Environmental Cleanup, 1995). However, this demonstration was unique in that four different ISESM technologies were compared at a single site.

- ISESM will be demonstrated at the DOE Kansas City Plant in the spring of 1996 . Mixing to a depth of 45 feet will be accomplished and additives such as potassium permanganate, lime and bionutrients will be tested.

\section{KEY RESULTS}

In situ treatment of VOCs in clay soils was effectively ( $>85 \%$ reduction ) and rapidly accomplished at acceptable costs.

- Vapor stripping processes-ambient air and hot air injection:

$\checkmark$ Treatment performance improved with longer mixing times. $50 \%$ of the target VOCs were removed in approximately 90 minutes, whereas 92 to $98 \%$ of the contaminants could be removed in the top fifteen feet of soil if mixing were continued for 225 minutes.

$\checkmark$ Extension of the zone of treatment to $22-\mathrm{ft}$ depth exhibited only a moderately reduced removal efficiency (i.e. average of approximately $88 \%$ ).

$\checkmark$ Soil bacteria levels were increased by several orders of magnitude following ambient air stripping. 


\section{SUMMARY}

continued

- In situ peroxidation:

0 In situ peroxidation was found to treat soil more rapidly than vapor stripping.VOC treatment efficiency was approximately $72 \%$ mass removal in 75 minutes to a depth of fifteen feet.

- In situ solidification:

$\checkmark$ VOC treatment efficiency was over $90 \%$. Limited VOCs were removed in the off-gas during grout injection and mixing.

- In situ treatment of VOCs in clay-rich soils was rapidly accomplished (e.g., $>15$ cubic yards per hour [yd $3 / \mathrm{h}]$ ).

- Treatment costs for each of the four technologies was comparable, ranging from $\$ 150$ to $\$ 200$ per cubic yard for the demonstration. Further experience has brought treatment costs down (see cost section).

- Use of a hydraulic probe for soil sampling with on-site VOC analyses, followed by three-dimensional visualization, provided enhanced information compared with conventional sampling, off-site analyses, and routine data treatment.

\section{CONTACTS}

\section{Technical}

Robert L. Siegrist, Principal Investigator, Oak Ridge National Laboratory (ORNL), (303) 273-3490.

\section{Management}

Dave Biancosino, DOE EM 50, DOE Plumes Focus Area Manager, (301) 903-7961.

Jim Wright, DOE Plumes Focus Area Implementation Manager, (803) 725-5608.

\section{Commercial vendors}

Jim Brannigan, Millgard Environmental Corporation, (313) 261-9760.

Steve Day, Geo-Con, Inc., (916) 858-0480. 


\section{SECTION 2}

\section{TECHNOLOGY DESCRIPTION}
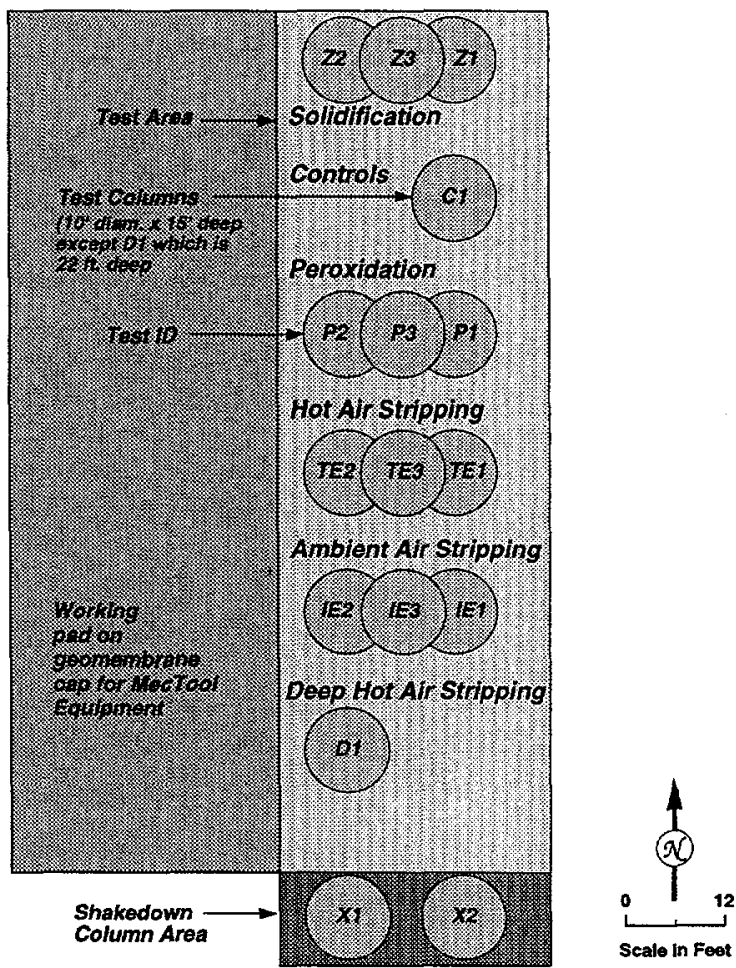

Schematic of the test site layout for the full-scale field demonstration in the X-231B unit.

\section{Overall Process Description}

- A mechanical system was employed to mix unsaturated or saturated contaminated soils while simultaneously injecting treatment or stabilization agents. The main system components include the following:

$\diamond \quad$ a crane-mounted soil mixing auger,

$\diamond$ a treatment agent delivery system,

$\diamond$ a treatment agent supply,

$\diamond$ an off-gas collection and treatment system.

- The mixing system used in the demonstration was manufactured and operated by Millgard Environmental Corporation, Livonia, MI. It is comprised of a track-mounted crane with a hollow, kelly bar attached to a drilling tool, known as the MecToolTM, consisting of one or two, 3- to 5-ft. long horizontal blades attached to a hollow vertical shaft, yielding an effective mixing diameter of 6 to 10 feet. Depths of 40 feet can be achieved with this equipment. The 10 -foot mixing diameter was used for this demonstration.

- Treatment agents were injected through a vertical, hollow shaft and out into the soil through 0.25 or 0.50 in. diameter orifices in the back side of the soil mixing blades. Treatment is achieved in butted or overlapped soil columns. Chemical Waste Management conducted the solidification/stabilization portion of the demonstration working in concert with Millgard Environmental Corporation.

- The ground surface above the mixed region was covered by a 14 -ft. diameter shroud under a low vacuum to contain any air emissions and direct them to an off-gas treatment process. The off-gas treatment system consisted of activated carbon filters followed by a HEPA filter.

- Removal of VOCs was enhanced by moving the mixing auger up and down from 2 to $15 \mathrm{ft}$ below ground surface during vapor stripping. 
- For the demonstration, a total of 14 soil columns, each $10 \mathrm{ft}$ in diameter, were treated.

$\checkmark$ Each of the four treatment processes were demonstrated in three soil columns, each $15 \mathrm{ft}$. deep. Two of each set of three columns were located in an undisturbed area, while a third, central column was placed to overlap the outer two by approximately $40 \%$.

$\checkmark$ One column was treated by the hot air stripping to a depth of $22 \mathrm{ft}$.

A single column, $15 \mathrm{ft}$. deep, was used for a tracer study.

$\checkmark$ The operating conditions for the demonstrations are summarized in Appendix B.

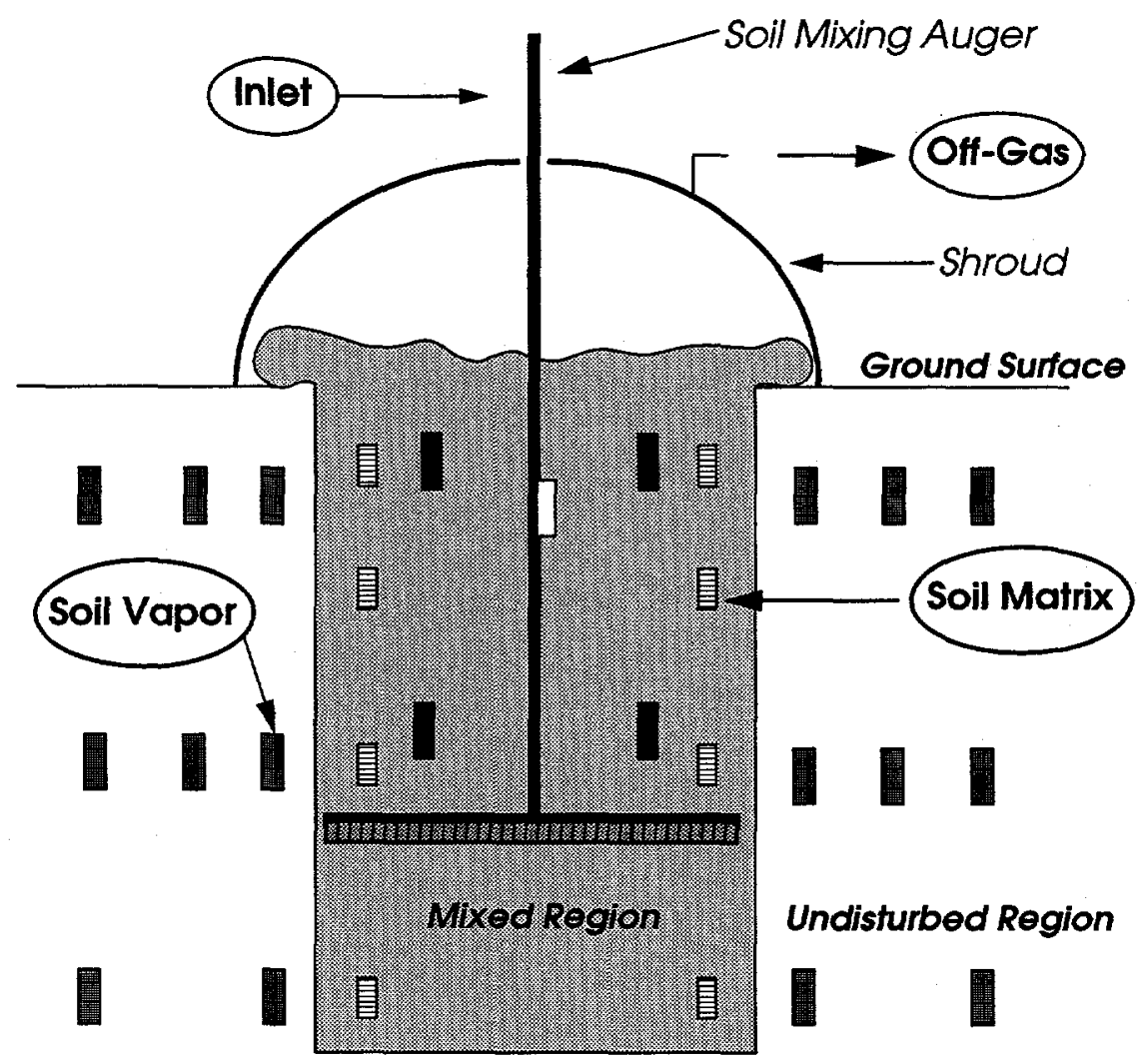

\section{Legend}

自 Pre- and post-treatment soil samples

Vapor implant in undisturbed soil, North/South of test column

IVapor implant in undisturbed soil, NE/SE of test column

(1. Vapor implant in mixed soil

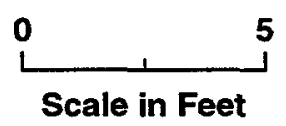

Profile view of a treated soil region and associated monitoring points.

- For the X-231B closure, a total of 628 soil columns with a depth of 22 feet were treated. The closure was completed by Geo-Con, using similar equipment. 


\section{SECTION 3}

\section{PERFORMANCE}

\section{Demonstration Plan}

- The goal of the ISESM technology demonstration was reduction in the target VOCs in the treatment zone of at least 70\%, to meet Ohio EPA performance standards.

- Primary monitoring and measurement activities included:

0 Pre-treatment and post-treatment soil sampling

- temperature

- VOCs

- particle-bound radioactivity

$\checkmark \quad$ In situ soil gas

- temperature

- pressure

- VOCs

$\diamond$ Operations data

- treatment depth

- processing times

- flow rate

- resource consumption

\section{Treatment Performance}

- A table of general observations of treatment performance for each of the four technologies is presented in Appendix B.

\section{Hot Air Vapor Stripping}

- Treatment performance for a 15 -ft. soil column:

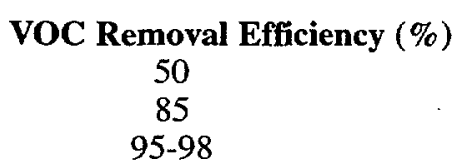

- VOC removal efficiency for the 22 -ft. soil column was approximately $88 \%$.

- The mass of VOCs removed as estimated by off-gas sampling generally was consistent with the reduction in soil VOCs estimated from pre-treatment and post-treatment sampling. These data indicated that VOCs were removed from the soil, rather than being forced into surrounding undisturbed soil. This assessment was confirmed by the absence of significant pressure or temperature effects on the unmixed region surrounding the treated columns.

- Off-gas temperatures increased from $\sim 25$ to $\sim 40^{\circ} \mathrm{C}$ after 225 minutes of treatment. Warming of the soil matrix was demonstrated by using thermocouples. Seventy hours after completion of hot air injection, soil matrix temperatures were $34^{\circ} \mathrm{C}$ and $37^{\circ} \mathrm{C}$ at depths of 3.5 and 9 feet, respectively. After 140 hours, temperatures remained elevated above background.

- Mixing created a berm of soil of approximately $15 \%$ of the treated region above the treated volume for both vapor stripping and peroxidation. 
- The figure below, illustrates the relationship between the position of the auger and the concentration of VOCs in the off-gas. The general decline in VOC concentrations with intermittent spikes suggested that VOCs were advectively removed from the gas-filled voids surrounding soil matrix clods while the auger passed through. Diffusion of VOCs from the soil matrix then replenished the gas-filled voids, which were later stripped during a subsequent pass of the auger.

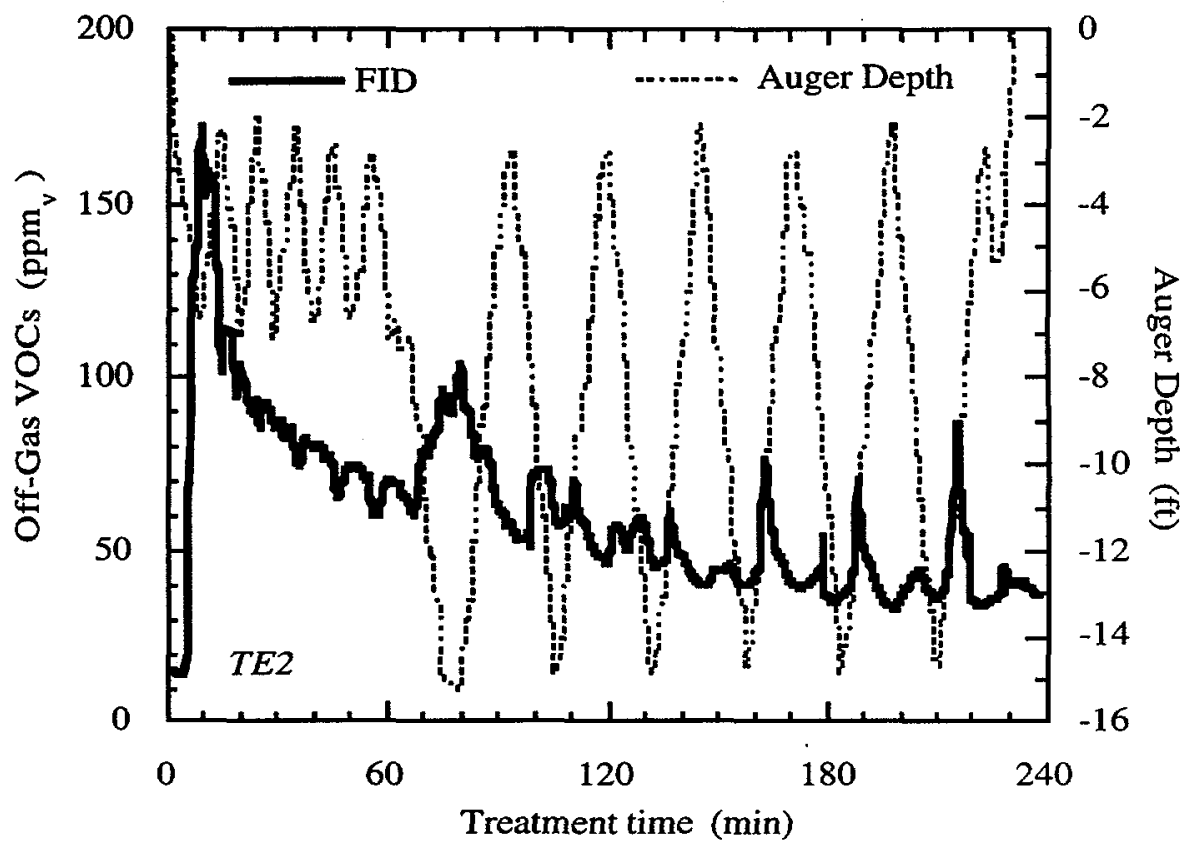

Auger position and off-gas VOC concentration for hot air column TE2.

\section{Ambient Air Vapor Stripping}

- The treatment performance achieved with ambient air injection was similar but slightly lower than that achieved with hot air. VOC removal efficiency for a 15 -ft. soil column:

VOC Removal Efficiency (\%)

50

85

92
Minutes of Operation

90

$140-180$

225

- Temperature of the off-gas increased gradually from $15^{\circ} \mathrm{C}$. initially to $30^{\circ} \mathrm{C}$. after 225 minutes of treatment. This gradual increase in off-gas temperature is believed to be due to warming of the soil matrix. Thermocouples placed in the soil revealed elevated temperatures of as much as $37^{\circ} \mathrm{C}$. Elevated temperatures persisted for more than 94 hours after treatment.

- The mass of VOCs removed as estimated by off-gas sampling generally was consistent with the reduction in soil VOCs estimated from pre-treatment and post-treatment sampling. These data indicate that VOCs were removed from the soil, rather than being forced into surrounding undisturbed soil. 


\section{PERFORMANCE}

\section{continued}

- The figure below illustrates the relationship between the position of the auger and the concentration of VOCs in the off-gas.

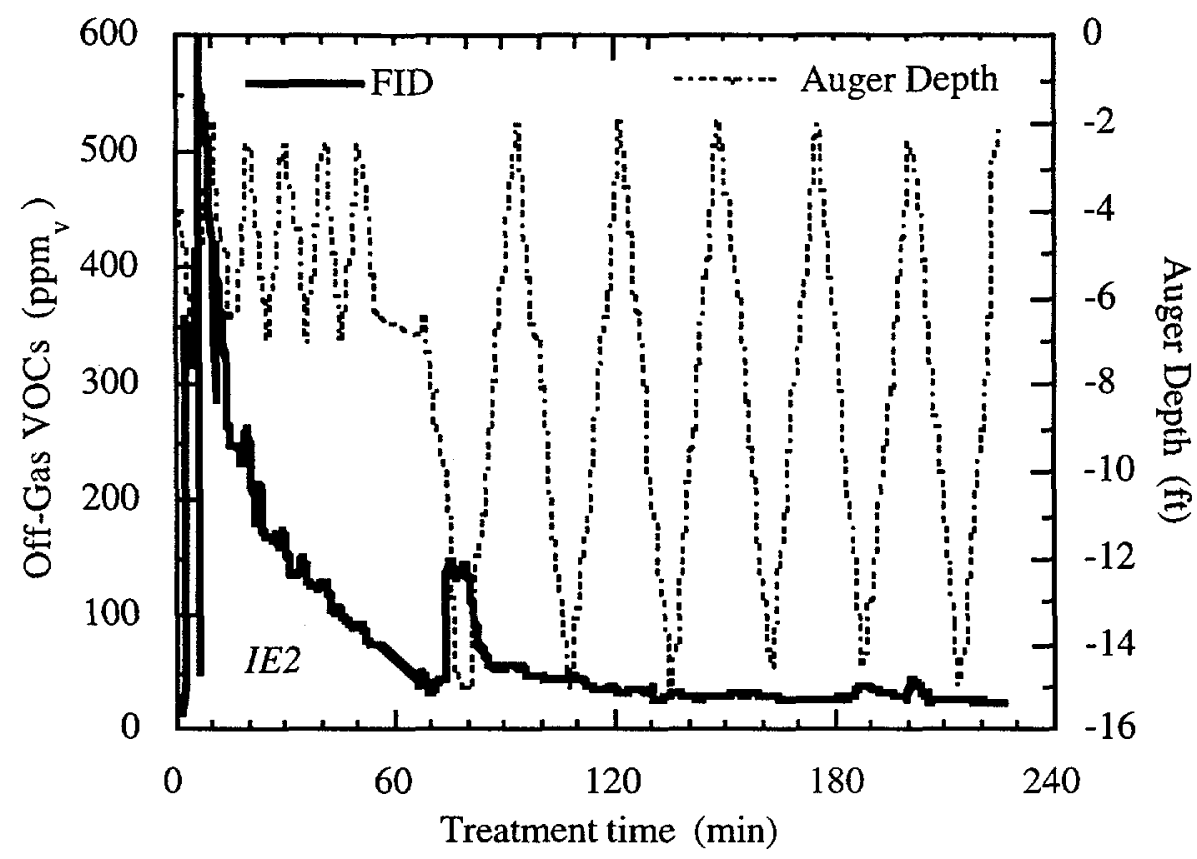

Auger position and off-gas VOC concentration for ambient air column IE2.

\section{Peroxidation Destruction}

- VOC removal efficiency for a 15 -ft. soil column averaged approximately $72 \%$ after 75 minutes of operation. This removal efficiency is faster than that shown for vapor extraction.

- The apparent VOC treatment efficiency (total \% removed) with peroxidation was below that achieved with both vapor extraction processes. This could have been due to:

$\diamond$ pre-treatment VOC concentrations were relatively low.

$\diamond$ in situ mixing only occurred for a short period of time (i.e., $60 \mathrm{~min}$.).

$\diamond$ off-gas collection system capacity was too low during the peroxidation test (system dysfunctioned). 
- The figure below illustrates the relationship between the position of the auger and the concentration of VOCs in the off-gas.

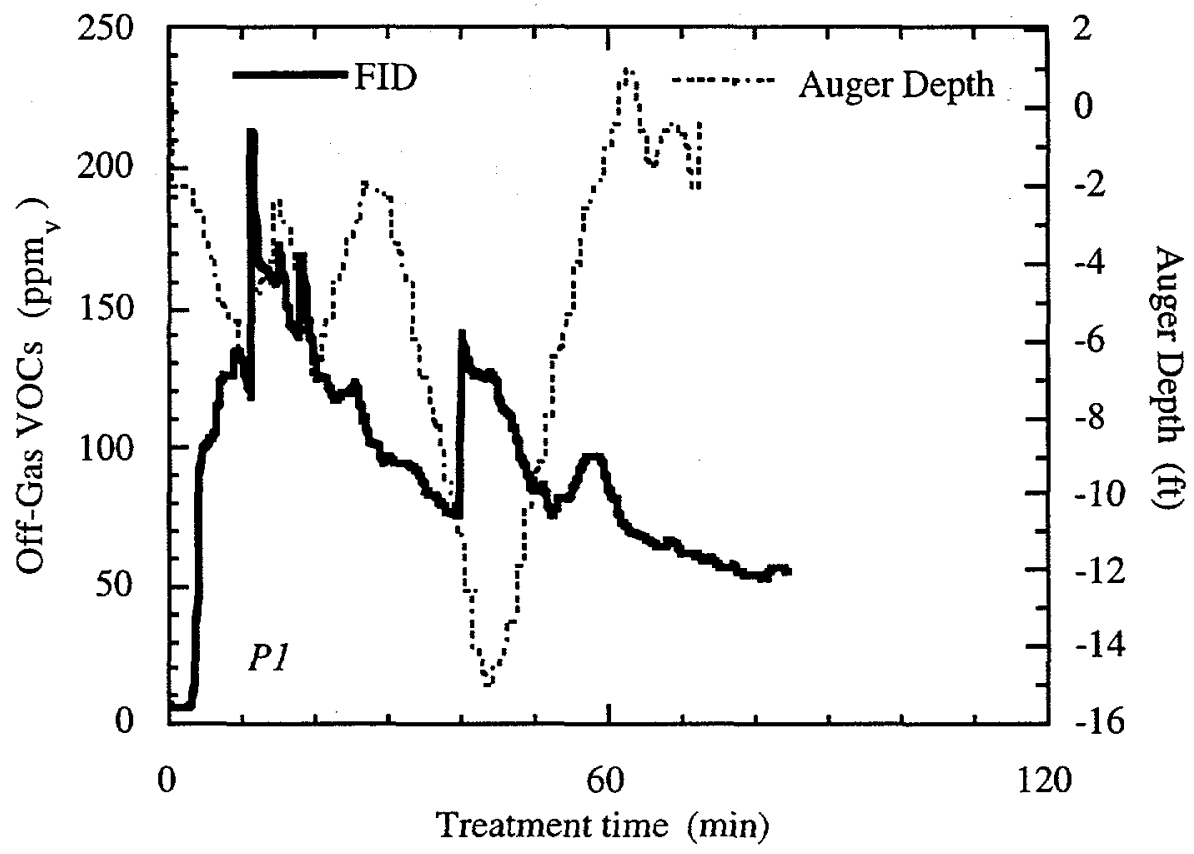

Auger position and off-gas VOC concentration for peroxidation column P1.

- During the peroxidation test, the off-gas collection system malfunctioned yielding a flow rate of roughly $30 \%$ of the air injection rate. This could have adversely affected the VOC treatment efficiency by altering the extraction of VOCs as well as the distribution of the peroxide mist.

\section{Solidification/Stabilization}

- During in situ mixing and grout injection, the concentrations of VOCs in the off-gas were at least an order of magnitude less than that obtained from the columns treated by vapor extraction/air injection. Because grout was applied before soil mixing was initiated and because the grout application rate was rapid, little volatization of VOCs is believed to have occurred as mixing proceeded.

- Total VOC concentrations in untreated soil ranged from 0.1 to over $500 \mathrm{mg} / \mathrm{kg}$. Total VOCs in the uncured grout/soil mixture were markedly lower than in untreated soil when compared by depth. Analytical problems with measurement of VOCs in grout may be responsible for the uncertainty in the mass balance for the VOCs.

- Toxicity Concentration Leaching Procedure (TCLP) concentrations for regulated constituents were either not detected or were well below EPA's regulatory limits. A few examples of the data collected are provided in Table 3, Appendix B.

- A comparison of physicochemical properties of untreated and solidified soil are provided in Appendix B.

0 The average bulk density of untreated soil $\left(1.95 \mathrm{~g} / \mathrm{cm}^{3}\right)$ was greater than that of the soil/grout specimens $\left(1.78 \mathrm{~g} / \mathrm{cm}^{3}\right)$. The decrease in bulk density after solidification may be due to the initial high bulk density of a clay-rich sample, which is reduced as a result of mixing. Also, the reduction in bulk density may be a result of entrapment/entrainment of air in the grout during mixing.

0 The compressive strength values ranged from 390 to $5200 \mathrm{kPa}$ (56 to $750 \mathrm{psig}$ ) and were inversely proportional to depth. Samples from the upper part of the core appeared to be highly grouted, while the deepest sample (13-14 ft.) appeared very fragile with a relatively small amount of grout material present. All values obtained, however, were greater than the currently accepted guideline of at least $340 \mathrm{kPa}$ (50 psig). 


\section{PERFORMANCE}

$\checkmark$ The hydraulic conductivity $\left(\mathrm{K}_{\text {sat }}\right)$ of cured grout/soil samples was two orders of magnitude greater than that of the untreated soil. This is probably due to disruption of the dense clay deposit as a result of mixing and increased porosity within the grout/soil mixture due to incomplete filling of the pores with grout.

$\checkmark$ The $\mathrm{pH}$ of the grout/soil mixture (10.3-11.5) was significantly higher than that of the untreated soil (5.3-7.5), presumably due to the high alkalinity of the cement-based grout. The stabilized soil/grout mixture should be more stable to acid attack.

$\checkmark$ Total volatile solids analyses revealed values ranging from 1.2 to $8.0 \mathrm{wt} \%$ throughout the solidified soil, with the values often lower than the corresponding value of the untreated soil column.

- The strengths and hydraulic conductivities measured are probably in error due to the sampling technique. Other projects using grout injection have demonstrated lower hydraulic conductivities and higher strengths.

- As a result of mixing the dense clay soil and injecting grout, an above-ground berm was created above each solidified column (approximately 1 meter high and equivalent to $30 \% \mathrm{v} / \mathrm{v}$ of the mixed region. The berms were eventually leveled out and compacted with vibratory equipment. 


\section{Technology Applicability}

- In situ soil mixing is commonly used in the construction industry. In situ soil mixing for stabilization has been commonly used at sites with soil contaminated with organics, but is also recognized as appropriate for metals-contaminated soils.

- ISESM with injection of hot air, ambient air, or hydrogen peroxide has been demonstrated to effectively remediate clayrich soils contaminated with VOCs in the unsaturated zone.

- ISESM is attractive for contaminated sites that contain low permeability soils that cannot be remediated using other technologies, such as in situ bioremediation. However, it can also be used in more permeable materials.

- ISESM is attractive for relatively small sites.

- ISESM requires surface access at all locations where soils are contaminated.

\section{Competing Technologies}

- ISESM as applied to sites like the X-231B site at Portsmouth competes with the following baseline technologies:

$\diamond$ excavation followed by on-site or off-site storage and/or treatment,

$\checkmark$ in-place containment by capping and slurry wall emplacement.

Other technologies that were considered for demonstration at the X-231B site are listed below..

\begin{tabular}{ll}
\hline Soil treatment technology & Technology description \\
\hline In situ immobilization & $\begin{array}{l}\text { Soil mixing by auger or jet system with addition of solidification/immobilization agent to solidify soil mass } \\
\text { and immobilize VOCs and other contaminants in place. }\end{array}$ \\
\hline In situ hot-air and/or steam stripping & $\begin{array}{l}\text { Soil mixing by dual auger system with injection of hot air and/or steam to raise soil temperature and volatilize } \\
\text { VoCs. }\end{array}$ \\
\hline In site electrokinetics & $\begin{array}{l}\text { Application of electrical energy to the soil mass in situ with induced mobility of water and ions toward a } \\
\text { capture electrode system. }\end{array}$ \\
\hline In situ jet mixing and slurry reactor & $\begin{array}{l}\text { In situ jet mixing with air or water to create an in-place slurry reactor that could be manipulated to achieve } \\
\text { physical, chemical, or biological processes for removal/degradation of voCs. }\end{array}$ \\
\hline In situ EM/RF heating & $\begin{array}{l}\text { In situ application of electromagnetic or radiofrequency energy to heat the soil mass in place and volatilize } \\
\text { VOCs. }\end{array}$ \\
\hline In site (ex situ) hydrogen peroxide & $\begin{array}{l}\text { Injection of hydrogen peroxide during soil mixing by a dual auger system or by jetting, or application ex situ. } \\
\text { VOCs are chemically oxidized, physically stripped, and/or destroyed. }\end{array}$ \\
\hline Ex situ thermal treatment & $\begin{array}{l}\text { Excavated soil is processed by thermal treatment during which VOCs are volatilized, captured, and/or } \\
\text { destroyed. }\end{array}$ \\
\hline Ex situ immobilization & Similar to in situ process, except excavated soil is treated above ground in a tank or container.
\end{tabular}

\section{Technology Maturity}

- The 1992 technology demonstration brought together existing technologies into new configurations or systems so that they could be applied in situ in low permeable media.

- For example, peroxidation destruction is commercially available for ex situ applications, however in situ treatment of soils is novel.

- Solidification/stabilization is well established for inorganics, but some questions remained for its effectiveness on organics. 


\section{SECTION 5}

\section{COST}

\section{Introduction}

- Information in this section was prepared from data provided in various project reports from the actual demonstration and from one of the vendors (Geo-Con). An independent cost analysis has not been performed.

\section{Capital Costs}

ISESM Actual Demonstration Costs (Jolley et al., 1991)

\begin{tabular}{|c|c|}
\hline Task Description & Estimated Cost \\
\hline Project Management & 199,500 \\
\hline Technical Task Plan Preparation & 15,750 \\
\hline Permits and Plans & 42,000 \\
\hline Procurement & 31,500 \\
\hline Treatability Studies & 31,500 \\
\hline Performance Monitoring & 73,500 \\
\hline Site Preparation and Equipment Installation & 42,000 \\
\hline Data Evaluation and Document Preparation & 42,000 \\
\hline \multirow{2}{*}{\multicolumn{2}{|c|}{$\begin{array}{l}\text { Labor } \\
\text { Travel (for equipment installation and monitoring }\end{array}$}} \\
\hline & \\
\hline by the ORNL team & 50,000 \\
\hline Supplies & 16,000 \\
\hline Materials and Subcontracts & 40,000 \\
\hline Treatability Studies & 150,000 \\
\hline \multicolumn{2}{|l|}{ On-Site Demonstration } \\
\hline Plans and Permits & 40,000 \\
\hline \multicolumn{2}{|l|}{ Site Preparation and Equipment Set-up } \\
\hline (included building a road to the site) & 100,000 \\
\hline \multicolumn{2}{|l|}{ Demonstration (approximately 2 weeks of } \\
\hline \multicolumn{2}{|l|}{ Demobilization and Site Restoration } \\
\hline (included recapping the site) & 60,000 \\
\hline Vendor Subcontracts & 500,000 \\
\hline Miscellaneous and Computer Support & 124,000 \\
\hline Analytical Support, QA, Waste Management & 150,000 \\
\hline Other (including G\&A and GPS) & 595,000 \\
\hline Total Actual Demonstration Costs & $1,956,000$ \\
\hline
\end{tabular}




\section{Demonstration Cost Analysis}

- Costs for equipment operation during demonstration treatment of three regions to a depth of up to $15 \mathrm{ft}$. are estimated at $\sim 20 \mathrm{~K} /$ day.

- ISESM with a smaller auger blade would reduce equipment mobilization and demobilization costs.

- For the demonstration, soil mixing costs were the same for each treatment process with minor cost variation between processes based on required materials and equipment ( $\$ 150$ to $\$ 200 / \mathrm{cy})$. Updated 1996 costs are estimated at $\$ 120$ $175 /$ cy or less. Further development of the technologies has shown that solidification is less costly than hot air injection.

$\checkmark$ Hot air vapor extraction costs were approximately $5 \%$ higher than for ambient air due to equipment; however, the process obtained similar performance goals faster. Treatment times (drilling/injection time only) for hot air stripping, deep hot air stripping and ambient air stripping were comparable and approximately 3 times slower than peroxidation and 5 to 7 times slower than in situ immobilization.

$\checkmark$ Additional costs are associated with required materials for peroxide destruction and solidification/stabilization, but both of these processes achieved treatment goals rapidly.

A technology selection table for the X-231B Site is located in Appendix C.

\section{Vendor Cost Analysis}

- Preliminary cost information is based on clean up of a contaminated site with the following characteristics:

- Area to be Treated: $\sim 29,000$ sq. ft ( $\sim 0.8$ acres) [460-10ft or 720-8ft columns]

- Depth of Contamination: from ground surface to $25 \mathrm{ft}$ deep

- Target Contaminants: VOCs

- Target Clean-up Goal: $90 \%$ destruction/removal/immobilization (total soil VOC concentration of less than $1 \mathrm{mg} / \mathrm{kg}$ )

- Other assumptions include:

- Mixing with stabilization assumes use of Portland cement $15 \%$ by weight. Ten columns per day are grouted. No offgas treatment is necessary for this application.

- Hot air injection assumes 5 columns per day. Each column is mixed for one hour.

- Jet mixing is calculated assuming using three-foot spacing on the columns. 3720 columns are required for treating the area. Eight columns per day are completed. Cement must be added at $25 \%$ by weight. Two single stem rigs are used for this application.

- No estimate for air monitoring, sampling, and testing is included.

- Security, utilities, grading, etc. are not included. Level D protective equipment is required and included.

- Cost for work at a government facility may be 10 to $50 \%$ higher.

- Costs are estimated by Geo-Con as of 1996. If the contract is written as performance based, additional mixing time should be priced on an hourly or cost-plus basis.

\section{Technique}

\section{Hot Air Injection}

Stabilization

Jet Mixing
Schedule (Production Weeks)

$8 \mathrm{ft}$. $\quad 10 \mathrm{ft}$.
Mobilization (\$)

$18.4 \quad 250,000$

14.4

9.2 55.8
250,000
150,000

70,000
Unit Costs (\$/cy)

$8 \mathrm{ft} . \quad 10 \mathrm{ft}$.

75

55

60

60
45

170 


\section{REGULATORYIPOLICY ISSUES}

\section{Regulatory Considerations}

- Early and continuous communication with the regulatory community is essential when assessing and determining the application of unproven or innovative technologies.

- At the Portsmouth Gaseous Diffusion Plant, the regulators were brought in to work with the site managers to select options for closure of the X-231B site. This early involvement streamlined the process for regulatory approval of the technology demonstration and also the later closure of the facility.

- Regulators in charge of ground water, surface water, RCRA, and the consent decree were all involved in the process.

- The technology demonstration was conducted by modifying the closure plan for the X-231B facility. No RD\&D Permit was required.

- The closure of the X-231B facility was approved by Ohio EPA, requiring a performance standard of $70 \%$ mass removal. Actual mass removal was greater than $87 \%$ for the closure. A RCRA cap was placed on the surface.

- Specific permits for this technology must be worked out with the appropriate regulators.

- Some type of air permit may be required because of the off-gas capture and treatment part of the system.

- An underground injection permit might be required if the treatment is occurring below the water table.

- CERCLA or RCRA permitting may be required.

- At federal facilities a NEPA review may be required.

\section{Safety, Risks, Benefits, and Community Reaction}

\section{Worker Safety}

- Potential worker safety risks for all the processes include those associated with standard drilling operations and potential exposure to VOCs and particulates in off-gas.

- Peroxide Injection: The hydrogen peroxide concentrations utilized were sufficiently low that it was not considered a hazardous material and its handling was of limited health and safety concern. While hydrogen peroxide at $5 \%$ by weight concentration is relatively harmless, it does require precautions in handling.

\section{Community Safety}

- ISESM with an operational off-gas treatment system does not produce any significant routine release of contaminants.

- No unusual or significant safety concerns are associated with transport of equipment, samples, waste, or other materials associated with ISESM.

\section{Environmental Impacts}

- ISESM disturbs the ground surface during operations. But because the site is remediated rapidly, long term effects are minimal.

- Operation of the equipment creates moderate noise in the immediate vicinity.

\section{Socioeconomic Impacts and Community Perception}

- ISESM has a minimal economic or labor force impact.

- The general public has limited familiarity with ISESM. 


\section{SECTION 7}

\section{LESSONS LEARNED}

\section{Design Issues}

- The equipment utilized for all process components was commercially available. However, the equipment may need to be specially modified for a particular application.

- More recent experience suggests that an 8-ft. diameter auger may be optimum for this type of application.

- Hot Air Injection:

- The orifices in the 2-arm, 10-ft. diameter tool were reduced to $0.25 \mathrm{in}$. from the ambient air size of $0.5 \mathrm{in}$. to increase the back pressure and enable maintenance of higher temperatures, thus encouraging further volatilization of contaminants.

- A compressor operator was required to manually control system airflow, temperature, and pressure. However, the system has now been modified to be controlled automatically.

- Peroxidation:

- Peroxide must be delivered by tank truck or rail car to meet required treatment processing.

- Solidification/Stabilization:

- Laboratory treatability studies were performed to test the best grout formulation. The grout recommended contained $25 \%$ cement, $10 \%$ granular activated carbon, fly ash to increase fluidity and a retarder. Other more simple and less costly formulations have been successfully used at other locations.

\section{Implementation Considerations}

General observations regarding operation of each treatment process tested at the X-231B site. $\underline{a}$

\begin{tabular}{|c|c|c|c|c|}
\hline Technology & $\begin{array}{l}\text { Soil treatment } \\
\text { rate } b\end{array}$ & $\begin{array}{l}\text { Operational } \\
\text { simplicity and } \\
\text { stability }\end{array}$ & Safety issues & $\begin{array}{l}\text { Secondary waste } \\
\text { generation }\end{array}$ \\
\hline Hot air vapor stripping & -15 c.y. per hour. & $\begin{array}{l}\text { Only requires an } \\
\text { air compressor. }\end{array}$ & $\begin{array}{l}\text { Heavy equipment operation; } \\
\text { compressed hot air. }\end{array}$ & $\begin{array}{l}\text { Off-gas and } \\
\text { decontamination fluids. }\end{array}$ \\
\hline $\begin{array}{l}\text { Ambient air vapor } \\
\text { stripping }\end{array}$ & -15 c.y. per hour. & $\begin{array}{l}\text { Only requires an } \\
\text { air compressor. }\end{array}$ & $\begin{array}{l}\text { Heavy equipment operation; } \\
\text { compressed air. }\end{array}$ & $\begin{array}{l}\text { Off-gas and } \\
\text { decontamination fluids. }\end{array}$ \\
\hline Peroxidation & -45 c.y. per hour. & $\begin{array}{l}\text { Requires chemical } \\
\text { injection system }\end{array}$ & $\begin{array}{l}\text { Heavy equipment operation; } \\
\mathrm{H}_{2} \mathrm{O}_{2} ; \text { compressed air. }\end{array}$ & $\begin{array}{l}\text { Off-gas, excess } \mathrm{H}_{2} \mathrm{O}_{2} \text {, } \\
\text { and decontamination } \\
\text { fluids. }\end{array}$ \\
\hline Solidification & -45 c.y. per hour. & $\begin{array}{l}\text { Requires grout injection } \\
\text { system. }\end{array}$ & $\begin{array}{l}\text { Heavy equipment operation; } \\
\text { grout handling equipment. }\end{array}$ & $\begin{array}{l}\text { Off-gas, excess grout, } \\
\text { and decontamination } \\
\text { fluids. }\end{array}$ \\
\hline
\end{tabular}

3 The information shown is preliminary and intended for general comparison only.

b Soil treatment rates (per equipment operating) were estimated assuming a process treatment efficiency of 70 to $95 \%$.

- Injection of grout for solidification/stabilization required adjustments, including those made in the field. The grout formulation was adjusted by:

- changing from powdered to granular activated carbon,

- adding fly ash to increase the consistency and fluidity of the grout,

- adding a retarder to provide a working time of 2 hours,

- adding water to the grout at the site to further increase workability. 


\section{LESSONS LEARNED}

- In situ solidification of contaminated soil materials was more complicated than originally anticipated. This was due in part to the difficulty in effectively mixing the dense clay soils in situ and to delivering the proper volume of grout of the appropriate formulation. There are likely to be infield adjustments to the grout formulation and injection volume after working knowledge of the grout delivery system and the site conditions are acquired. Field experience since the demonstration has improved the process to make it more effective and efficient.

- Generation of secondary liquid wastes, namely waste grout from the delivery trucks and from rinsing out the mixing equipment, could be appreciable in the solidification process operation. An improved "grout-on-demand" system has been developed to minimize waste.

\section{Technology Limitations/ Needs for Future Development}

- Potential enhancements to the ISESM approach include:

$\checkmark$ more mobile and scaled down mixing equipment

$\checkmark$ more efficient coupling of treatment processes

- Other technologies may be coupled to the ISESM process as a post-soil mixing enhancement:

$\diamond$ passive treatment processes for in situ treatment

$\vartheta$ soil vapor extraction

$\vartheta$ bioremediation

- Other reagent additives should be examined as alternatives:

$\checkmark$ other oxidants (e.g., permanganate, ozone)

$\diamond$ reductants (e.g., zero-valence metals)

0 sorbents (e.g., peat or zeolites).

- Improvements in equipment and experience will eventually reduce costs further. 


\section{DEMONSTRATION SITE CHARACTERISTICS}

\section{Background}

- The DOE Portsmouth Gaseous Diffusion Plant is located approximately 70 miles south of Columbus in southern Ohio.

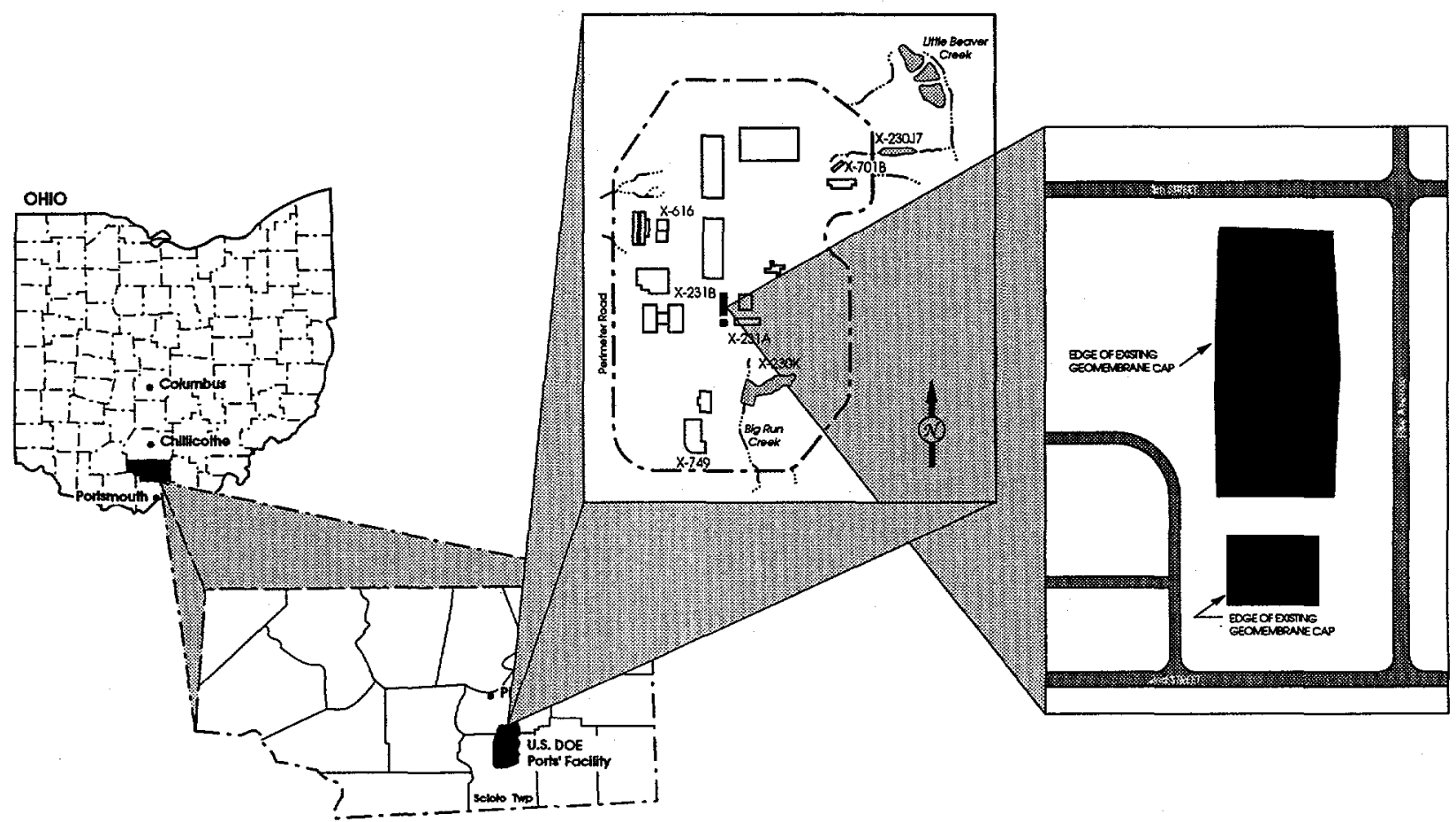

Location of the DOE Portsmouth Gaseous Diffusion Plant and the X-231B Unit

- The X-231B waste management unit consists of two adjacent waste oil biodegradation areas. The X-231B Unit encompasses about 0.8 acres and was reportedly used from 1976 to 1983 for the treatment and disposal of waste oils and degreasing solvents, some containing uranium-235 $(235 \mathrm{U})$ and technetium-99 $\left({ }^{99} \mathrm{Tc}\right)$. TCE and other VOCs remained in the soil and spread into the shallow ground water. 


\section{Site Characterization}

- Physical, chemical and biological properties of subsurface soil at the X-231B site as measured in samples collected in 1990.

\begin{tabular}{|c|c|c|c|c|c|c|}
\hline \multirow[b]{3}{*}{ Characteristic $\stackrel{a}{a}$} & \multicolumn{6}{|c|}{ Nominal depth and boring location } \\
\hline & \multicolumn{3}{|c|}{ Shallow (7-ft depth) } & \multicolumn{3}{|c|}{ Deep (17-ft depth) } \\
\hline & SB01 & SB02 & SB03 & SB01 & SB02 & SB03 \\
\hline Depth, $\mathrm{ft}$ & 7.2 & 6.2 & 6.2 & 17.2 & 17.2 & 17.2 \\
\hline \multicolumn{7}{|l|}{ Particle size distribution: } \\
\hline Clay: $<0.002 \mathrm{~mm}$, wt $\%$ & 22.5 & na & 25.0 & 14.0 & 12.0 & 15.0 \\
\hline Silt: $0.002-0.05 \mathrm{~mm}$, wt $\%$ & 65.5 & na & 67.0 & 64.0 & 55.0 & 39.0 \\
\hline Sand: $0.05-2.0 \mathrm{~mm}, \mathrm{wt} \%$ & 12.0 & na & 8.0 & 22.0 & 33.0 & 46.0 \\
\hline Water content, dry wt \% & 17.6 & na & 19.0 & 23.5 & 23.5 & 22.0 \\
\hline Percent solids, wt\% & 86.6 & na & 81.0 & 81.8 & 81.0 & 81.2 \\
\hline $\mathrm{pH}$ & 5.32 & na & 5.96 & 7.40 & 6.16 & 7.01 \\
\hline Total organic carbon, mg/kg & 579 & na & 1190 & 245 & 184 & 472 \\
\hline Kjeldahl nitrogen, $\mathrm{mg} / \mathrm{kg}$ & $<500$ & na & $<500$ & $<500$ & $<500$ & $<500$ \\
\hline Total phosphorus, $\mathrm{mg} / \mathrm{kg}$ & 66 & na & 66 & 66 & 73 & 108 \\
\hline Total sulfur, $\mathrm{mg} / \mathrm{kg}$ & 24 & na & $<10$ & 23 & 30 & $<10$ \\
\hline \multicolumn{7}{|l|}{ Exchangeable cations: $b$} \\
\hline Calcium, $\mathrm{mg} / \mathrm{L}$ & 47 & na & 48 & 60 & 37 & 71 \\
\hline Magnesium, mg/L & 42 & na & 31 & 28 & 25 & 34 \\
\hline Sodium, mg/L & 9.4 & na & 6.0 & 10.6 & 3.1 & 15.1 \\
\hline Potassium, mg/L & 6.3 & na & 4.5 & 6.0 & 4.0 & 5.0 \\
\hline Percent moistures, wt $\%$ & 17.9 & 18.7 & 20.1 & 23.0 & 23.5 & 23.4 \\
\hline Liquid limits, wt\% & na & na & na & 25.30 & 25.55 & 25.73 \\
\hline Plastic limitc, wt\% & na & na & na & 22.19 & 22.63 & 20.56 \\
\hline Plasticity indexs, wt $\%$ & na & na & na & 3.11 & 2.92 & 5.17 \\
\hline Total bacteria, $\mathrm{CFU} / \mathrm{g}$ & $2.26 \mathrm{E} 04$ & $2.37 \mathrm{E} 05$ & $1.02 \mathrm{E} 04$ & $<1 \mathrm{E} 02$ & $<1 \mathrm{E} 02$ & $<1 \mathrm{E} 02$ \\
\hline Methanotrophs, & Detected & Detected & Detected & $\begin{array}{c}\text { Not } \\
\text { Detected }\end{array}$ & $\begin{array}{c}\text { Not } \\
\text { Detected }\end{array}$ & $\begin{array}{c}\text { Not } \\
\text { Detected }\end{array}$ \\
\hline
\end{tabular}

na Indicates analyses not performed.

a Results of analyses are expressed on a field moist soil weight basis unless otherwise indicated.

b Averages of duplicate analyses; coefficient of variation for duplicates was $<5 \%$.

s Percent moisture (wet wt. \%) analyses performed by Geraghty \& Miller, Inc., Dublin, Ohio.

- Contaminants of Concern

0 Soil

- Thirteen VOCs were identified with the following being most prevalent and at the highest concentrations (i.e., several hundred to several thousand micrograms per kilogram).

trichloroethylene (TCE)

1,1,1-trichloroethane (TCA)

1,1-dichloroethylene (1,1-DCE)

methylene chloride

- The highest concentrations were found in the unsaturated zone ( 7-ft depth) near the center of the plot.

- Low levels of ${ }^{235 \mathrm{U}}$ and ${ }^{99} \mathrm{Tc}$ are also present.

$\checkmark$ Ground water

- The shallow ground water was also contaminated with some contaminants at levels well above drinking water standards. 


\section{Contaminant Locations and Hydrogeologic Profiles}

- Ground water underneath the X-231B unit occurs in two aquifer systems: the Minford/Gallia Members and the Berea Sandstone. Existing site characterization data revealed that beneath the X-231B unit were fluvio-lacustrine silts and clays (Minford Member of the Teays Formation) underlain by silty sand and gravel (Gallia Member). The Gallia Member lies at a depth of approximately $25 \mathrm{ft}$ and typically does not exceed $4 \mathrm{ft}$ in thickness. Bedrock below the Gallia is the Mississippian age Sunbury Shale. The Sunbury Shale is 10 to $12 \mathrm{ft}$ thick, slightly fractured, and has very low permeability. The water table in this area is approximately 10 to $14 \mathrm{ft}$ below ground surface (bgs). Ground water flow occurs vertically through the Minford Member into the Gallia Member where flow is predominantly horizontal to the southeast toward a surface impoundment.

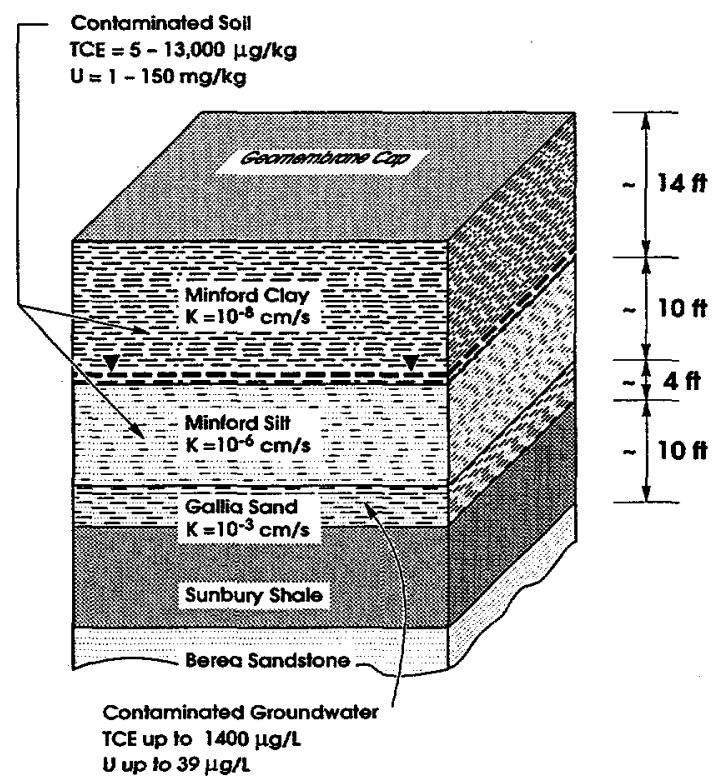

Subsurface characteristics beneath the X-231B Unit.

- Thirty-six groundwater monitoring wells have been installed in the vicinity of the X-231B unit. Twenty-five wells have been installed and screened within the Gallia deposit, but only three wells have been screened in the overlying Minford. Eight wells penetrate into the underlying bedrock (i.e., Sunbury or Berea).

- The hydraulic conductivities of all the shallow units are low. Laboratory measurements revealed a saturated hydraulic conductivity $\left(\mathrm{K}_{\mathrm{saa}}\right)$ of only 0.00023 feet per day ( $\left.\mathrm{ft} / \mathrm{d}\right)$ for the Minford clay and $0.0043 \mathrm{ft} / \mathrm{d}$ for the Minford silt. Field pumping tests yielded a substantially higher mean $\mathrm{K}_{\text {sat }}$ for the Gallia deposit of $7.1 \mathrm{ft} / \mathrm{d}$. The lower portion of the Minford is in hydraulic continuity with the Gallia.

- The permeability of the Sunbury Shale is believed to be very low. Although thin and slightly fractured, the Sunbury may hydraulically isolate the underlying Berea from the overlying unconsolidated aquifer (i.e., Minford/Gallia).

- Several VOCs (e.g., TCE and 1,1,1-TCA) are present throughout the Minford Member under the X-231B site from the ground surface to approximately $25 \mathrm{ft}$ bgs. These same contaminants are present in the shallow ground water underneath and up to $750 \mathrm{ft}$ downgradient from the X-231B Unit boundaries. The primary soil and ground water contaminant is TCE, which is present in the ground water at levels above federal drinking water standards.

- The Minford deposit beneath the X-231B Unit extends from the ground surface to approximately 22- to 24-ft depth. The Minford is comprised of an upper zone (top $12 \mathrm{ft}$ or so) that is finer textured than the lower zone. Intensive sampling and analysis of the Minford deposit was conducted to delineate the contaminant distribution throughout the deposit to enable development of the treatment locations for the field test. Analysis of the results of this work revealed that approximately $78 \%$ of the VOCs are located in the upper $12 \mathrm{ft}$, above the water table. As a result, the field test was designed to focus on treatment of the unsaturated portion of the Minford deposit (i.e. the upper $15 \mathrm{ft}$ ). In addition, a single test was conducted to a depth of approximately $22 \mathrm{ft}$ to provide some operational information for treatment of the lower Minford deposit, located below the water table. 


\section{TECHNOLOGY DESCRIPTION/PERFORMANCE DETAIL}

\section{Summary of Operating Conditions}

\begin{tabular}{|c|c|c|c|c|c|c|c|c|}
\hline \multicolumn{2}{|c|}{ Operating Parameters } & Units & & $\begin{array}{l}\text { Hot Air } \\
\text { Stripping }\end{array}$ & $\begin{array}{c}\text { Hot Air } \\
\text { Stripping - } \\
\text { Deep }\end{array}$ & $\begin{array}{c}\text { Ambient Air } \\
\text { Stripping }\end{array}$ & $\begin{array}{l}\text { Peroxidation } \\
\text { Destruction }\end{array}$ & $\begin{array}{l}\text { Solidification } \\
\text { Stabilization }\end{array}$ \\
\hline \multicolumn{2}{|c|}{ Auger rotation speed } & rpm & & 5 to 10 & 5 to 10 & 5 to 10 & 5 to 10 & 5 to 10 \\
\hline \multicolumn{2}{|c|}{ Auger vertical movement rate } & fpm & & 1 & 1 & 1 & 1 & 1 to 3 \\
\hline \multicolumn{2}{|c|}{ Mixed region diameter } & $\mathrm{ft}$ & & 10 & 10 & 10 & 10 & 10 \\
\hline \multicolumn{2}{|c|}{ Mixed region depth } & $\mathrm{ft}$ & & 15 & 22 & 15 & 15 & 15 \\
\hline \multicolumn{2}{|c|}{ Mixed region volume } & $\mathrm{cf}$ & & 1180 & 1730 & 1180 & 1180 & - \\
\hline \multicolumn{2}{|c|}{ Air delivery rate } & $\mathrm{cfm}$ & & $1000-1400$ & $1000-1400$ & $1000-1400$ & $\begin{array}{c}800 \\
\text { initially, } \\
\text { reduced to } 300\end{array}$ & 0 \\
\hline \multicolumn{2}{|c|}{ Air exchange in soil column } & $\mathrm{RV} / \mathrm{min}$ & & $0.8-1.2$ & $0.6-0.8$ & $0.8-1.2$ & - & - \\
\hline \multicolumn{2}{|c|}{ Air temperature at the source } & ${ }^{o} \mathrm{~F}$ & & 250 & 250 & 90 & 90 & - \\
\hline \multicolumn{2}{|c|}{ Air pressure at the source } & psig & & 180 & 180 & 100 & 80 & - \\
\hline \multicolumn{2}{|c|}{ Shroud vacuum } & in. $\mathrm{H}_{2} \mathrm{O}$ & & $\sim 5$ & $\sim 5$ & -5 & - & -5 \\
\hline \multicolumn{2}{|c|}{ Peroxide injection rate } & gpm & & - & - & - & 7.5 & - \\
\hline \multicolumn{2}{|c|}{ Peroxide injection volume } & vol./vol. & & - & - & - & ave. of 0.07 & - \\
\hline \multicolumn{2}{|c|}{ Peroxide concentration } & $w t \%$ & & - & - & - & 5 & - \\
\hline \multicolumn{2}{|c|}{ Grout injection rate } & vol. $\%$ & & - & - & - & - & 30 \\
\hline \multicolumn{2}{|c|}{ Off-gas flow rate } & $\mathrm{cfm}$ & & - & - & - & - & $100-120$ \\
\hline \multicolumn{9}{|c|}{ Treatment cycles } \\
\hline \multicolumn{2}{|c|}{0 to $7 \mathrm{ft}$ zone } & down/up & & 8 & 8 & 8 & 2 & \\
\hline \multicolumn{2}{|c|}{7 to $15 \mathrm{ft}$ zone } & down/up & & 4 & 4 & 4 & 1 & \\
\hline \multicolumn{2}{|c|}{0 to $15 \mathrm{ft}$ zone } & down/up & & & & & & 3 to 4 \\
\hline \multicolumn{2}{|c|}{ Treatment time per column } & $\min$ & & 225 & 225 & 225 & 75 & 30 to 45 \\
\hline - & approximately & & $\mathrm{cf}$ & cubic feet & & & & \\
\hline & cubic feet per minute & & fpm & feet per $m$ & & & & \\
\hline gpm & gallons per minute & & $\circ$ & degrees $\mathrm{Fa}$ & nheit & & & \\
\hline in $\mathrm{H}_{2} \mathrm{O}$ & inches of water & & $\min$ & minutes & & & & \\
\hline psig & pounds/square inch (gauge) & & $\mathrm{RV} / \mathrm{min}$ & n reactor vo & es/minute & & & \\
\hline vol\% & per cent by volume & & wt\% & per cent b & & & & \\
\hline
\end{tabular}




\section{Treatment Performance: General Observations}

General Observations for Each Treatment Process Tested at the X-231B Site.

\begin{tabular}{|c|c|c|c|c|c|}
\hline $\begin{array}{l}\text { Technology } \\
\text { and } \\
\text { components }\end{array}$ & $\begin{array}{c}\text { VOC } \\
\text { treatment } \\
\text { process }\end{array}$ & $\begin{array}{c}\text { VOC } \\
\text { removal } \\
\text { efficiency }\end{array}$ & $\begin{array}{c}\text { Effect on } \\
\text { non-VOC } \\
\text { contaminants }\end{array}$ & $\begin{array}{l}\text { Effect on } \\
\text { soil } \\
\text { properties }\end{array}$ & $\begin{array}{c}\text { Effect on } \\
\text { unmixed adja- } \\
\text { cent soil }\end{array}$ \\
\hline $\begin{array}{l}\text { Hot Air Vapor } \\
\text { Stripping. An air } \\
\text { compressor to deliver } \\
\sim 1400 \mathrm{cfm} \text { of } 250^{\circ} \mathrm{F} \\
\text { air through a hollow } \\
\text { kelly bar via jets in a } \\
10 \mathrm{ft} \text {. auger. }\end{array}$ & $\begin{array}{l}\text { Mass transfer and } \\
\text { advective removal for } \\
\text { ex situ capture and } \\
\text { destruction }\end{array}$ & $\begin{array}{l}>95 \% \text { mass removal } \\
\text { after } 3.75 \mathrm{hr} \text { of } \\
\text { treatment in a } 10 \mathrm{ft} \text {. } \\
\text { diameter by } 15 \mathrm{ft} \text {. } \\
\text { deep column. }\end{array}$ & $\begin{array}{l}\text { Limited if any; stimu- } \\
\text { lation of biological } \\
\text { activity and possible } \\
\text { degradation of } \\
\text { SVOCs }\end{array}$ & $\begin{array}{l}\text { Disrupts natural soil } \\
\text { structure. Injection } \\
\text { of hot air stimulated } \\
\text { some increased } \\
\text { biological activity. }\end{array}$ & $\begin{array}{l}\text { Limited impact on } \\
\text { soil gas concentra- } \\
\text { tions or pressure. }\end{array}$ \\
\hline $\begin{array}{l}\text { Ambient Air Vapor } \\
\text { Stripping. An air } \\
\text { compressor to deliver } \\
\sim 1400 \mathrm{cfm} \text { of } 90^{\circ} \mathrm{F} \text { air } \\
\text { through a hollow } \\
\text { kelly bar via jets in a } \\
\text { 10ft. auger. }\end{array}$ & $\begin{array}{l}\text { Mass transfer and } \\
\text { advective removal } \\
\text { for ex situ capture } \\
\text { and destruction }\end{array}$ & $\begin{array}{l}>90 \% \text { mass removal } \\
\text { after } 3.75 \mathrm{hr} \text { of } \\
\text { treatment in a } 10 \mathrm{ft} . \\
\text { diameter by } 15 \mathrm{ft} \text {. } \\
\text { deep column. }\end{array}$ & $\begin{array}{l}\text { Limited if any; stimu- } \\
\text { lation of biological } \\
\text { activity and possible } \\
\text { degradation of } \\
\text { SVOCs }\end{array}$ & $\begin{array}{l}\text { Disrupts natural soil } \\
\text { structure. Injection of } \\
\text { air stimulates markedly } \\
\text { increased biological } \\
\text { activity. }\end{array}$ & $\begin{array}{l}\text { Limited impact on } \\
\text { soil gas concentra- } \\
\text { tions or pressure. }\end{array}$ \\
\hline $\begin{array}{l}\text { Peroxidation. An air } \\
\text { compressor to deliver } \\
-300 \mathrm{cfm} \text { of } 90^{\circ} \mathrm{F} \text { and } \\
7 \% \mathrm{v} / \mathrm{v} \text { addition of } 5 \\
\text { wt } \% \mathrm{H}_{2} \mathrm{O}_{2} \text { in air } \\
\text { through a hollow } \\
\text { kelly bar via jets in a } \\
10 \mathrm{ft} \text { auger. } \\
\end{array}$ & $\begin{array}{l}\mathrm{H}_{2} \mathrm{O}_{2} \text { interacts with } \\
\text { soil Fe to oxidize } \\
\text { vOCs in situ. } \\
\text { Limited VOCs in } \\
\text { off-gas are captured } \\
\text { for destruction }\end{array}$ & $\begin{array}{l}>70 \% \text { mass removal } \\
\text { after } 1 \mathrm{hr} \text { of treatment } \\
\text { in a } 10 \mathrm{ft} \text {. diameter by } \\
15 \mathrm{ft} \text {. deep column. }\end{array}$ & $\begin{array}{l}\text { Increased binding of } \\
\text { metals. Preoxidation } \\
\text { of SVOCs for } \\
\text { biodegradation. }\end{array}$ & $\begin{array}{l}\text { Mixing disrupts natur- } \\
\text { al soil structure. } \\
\text { Injection of } \mathrm{H}_{2} \mathrm{O}_{2} \text { does } \\
\text { not "sterilize" soil. } \\
\mathrm{H}_{2} \mathrm{O}_{2} \text { can reduce soil } \\
\text { permeability of clays. }\end{array}$ & $\begin{array}{l}\text { Limited impact on } \\
\text { soil gas concentra- } \\
\text { tions or pressure. }\end{array}$ \\
\hline $\begin{array}{l}\text { Solidification. } \\
\text { An injection system to } \\
\text { deliver } \sim 1.5 \mathrm{cfm} \text { of } \\
30 \% \mathrm{v} / \mathrm{v}(20 \% \mathrm{wt} / \mathrm{wt}) \\
\text { grout through a hol- } \\
\text { low kelly bar via jets } \\
\text { in a } 10 \mathrm{ft} . \text { auger. }\end{array}$ & $\begin{array}{l}\text { Grout solidifies the } \\
\text { soil and immobilizes } \\
\text { the VOCs in situ. } \\
\text { Limited VOCs in off- } \\
\text { gas are captured for } \\
\text { destruction by either } \\
\text { carbon adsorption, } \\
\text { catalytic oxidation, } \\
\text { biotreatment, etc. }\end{array}$ & $\begin{array}{l}>90 \% \text { apparent } \\
\text { capture of VOCs in } \\
\text { preset grout/soil mix } \\
\text { after } 1 \mathrm{hr} \text { of treatment } \\
\text { in a } 10 \mathrm{ft} \text {. diameter by } \\
15 \mathrm{ft} \text {. deep column. }\end{array}$ & $\begin{array}{l}\text { Encapsulation and } \\
\text { stabilization of metals } \\
\text { in grout. }\end{array}$ & $\begin{array}{l}\text { Mixing disrupts } \\
\text { natural soil structure. } \\
\text { Injection of grout } \\
\text { reduces permeability } \\
\text { significantly. }\end{array}$ & $\begin{array}{l}\text { Limited impact on } \\
\text { soil gas concentra- } \\
\text { tions or pressure. }\end{array}$ \\
\hline
\end{tabular}

\section{Treatment Performance: Post-demonstration Soil Chemical Analyses}

Results of selected TCLP analyses of grouted soil after in situ solidification.

\begin{tabular}{|c|c|c|c|c|c|}
\hline \multirow[b]{2}{*}{ Target analyte } & \multicolumn{2}{|c|}{$\begin{array}{l}\text { Cores collected at } 15 \text { months } \\
\qquad(\mathrm{mg} / \mathrm{L}) \text { a }\end{array}$} & \multicolumn{3}{|c|}{$\begin{array}{l}\text { Post-demonstration grout soil samples } \\
\qquad(\mathrm{mg} / \mathrm{L}) \underline{b}\end{array}$} \\
\hline & 4-5 ft. depth & $8-9$ ft. depth & 4-5 ft. depth & $8-9 \mathrm{ft}$. depth & $\begin{array}{l}\text { TCLP Limits } \\
(\mathbf{m g} / \mathbf{L})\end{array}$ \\
\hline Carbon Tetrachloride & $<0.025$ & $<0.025$ & $<0.15$ & $<0.15$ & 0.5 \\
\hline Benzene & $<0.025$ & $<0.025$ & $<0.09$ & $<0.09$ & 0.5 \\
\hline 1,2-Dichloroethane & $<0.025$ & $<0.025$ & $<0.10$ & $<0.10$ & 0.5 \\
\hline Trichloroethylene & 0.08 & $<0.025$ & $<0.22$ & $<0.22$ & 0.5 \\
\hline Barium & 9.4 & 2.9 & $\ldots$ & $\ldots$ & 100.0 \\
\hline Lead & $<0.05$ & $<0.05$ & $\ldots$ & $\ldots$ & 5.0 \\
\hline Uranium & $<0.0004$ & $<0.0004$ & $\ldots$ & ... & $\ldots$ \\
\hline
\end{tabular}

a Samples collected 15 months after in situ solidification in August 1993 and analyzed at ORNL Analytical Chemistry Division.

b Samples collected immediately following in situ solidification in May 1992 and analyzed at the Clemson Technical Center, Clemson, South Carolina. 


\section{APPENDIX B $\quad$ continued}

\section{Treatment Performance: Physicochemical Properties of Soil, Pre-and Post-Demonstration}

Physicochemical properties of the untreated and solidified X-231B soil.

\begin{tabular}{|c|c|c|c|c|c|}
\hline Sample description & $\begin{array}{c}\text { Sample } \\
\text { depth } \\
\text { (m) }\end{array}$ & $\begin{array}{c}\text { Water } \\
\text { content } \\
(w t \%) \text { a }\end{array}$ & $\begin{array}{c}\text { Bulk } \\
\text { density } \\
\left(\mathrm{g} / \mathrm{cm}^{3}\right)\end{array}$ & $\begin{array}{l}\text { Compressive } \\
\text { strength (kPa) }\end{array}$ & $\begin{array}{c}\text { Hydraulic } \\
\text { conductivity } \underline{b} \\
(\mathrm{~cm} / \mathrm{sec})\end{array}$ \\
\hline Untreated & $0.3-0.6$ & $20.5 \mathrm{~s}$ & & & \\
\hline \multirow{3}{*}{ control core } & $1.2-1.5$ & $16.9 \mathrm{~s}$ & 2.15 & $\ldots$ & $8.08 \times 10^{-8}$ \\
\hline & $2.4-2.7$ & $18.4 \mathrm{~s}$ & 1.75 & $\ldots$ & $\ldots$ \\
\hline & $3.9-4.2$ & $16.5 \&$ & $\ldots$ & $\ldots$ & $8.09 \times 10^{-8}$ \\
\hline \multirow[t]{4}{*}{ S/S core } & $0.3-0.6$ & 19 & $1.73 \varepsilon$ & $5200 \mathrm{~d}$ & $8.88 \times 10^{-6}$ \\
\hline & $1.2-1.5$ & 23.5 & $1.66 \varepsilon$ & 3500 & $\ldots$ \\
\hline & $2.4-2.7$ & 19 & 1.72 & 2600 & $\ldots$ \\
\hline & $3.9-4.2$ & 13.6 & $2.00 \mathrm{~s}$ & 390 & $7.75 \times 10^{-6}$ \\
\hline
\end{tabular}

a Analyses performed at $60^{\circ} \mathrm{C}$.

b All values represent at a minimum, the average of 6 replicate analyses. Data reported at $25^{\circ} \mathrm{C}$ per ASTM D5084. Permeant fluid $=0.005 \mathrm{M}$ CaSO 4

c Average of analyses of two samples.

d Sample taken at the 1-m depth. 


\section{TECHNOLOGY SELECTION DETAIL}

\section{Technology Selection}

Selection of the most promising technologies for demonstration at X-231B was accomplished by a ration ranking process. The approach enabled rigorous evaluation of each technology and provided results regarding implementation, operation and maintenance, performance and cost. The following table summarizes key information from this process for comparison of technologies.

\begin{tabular}{llll}
\hline Technology & $\begin{array}{l}\text { Estimated Time for } \\
\text { Installation \& Operation }\end{array}$ & Processing Rates & $\begin{array}{l}\text { Minimization of } \\
\text { Full-scale } \\
\text { Remediation Costs }\end{array}$ \\
\hline In situ immobilization & 1 month & $1000 \mathrm{cy} / \mathrm{d}$ & 54 \\
\hline In situ hot air/steam stripping & rapid & 3 to $10 \mathrm{cy} / \mathrm{hr}$ & 50 \\
\hline In situ electrokinetics & $\begin{array}{l}\text { additional research required } \\
\text { prior to voC application }\end{array}$ & $\mathrm{N} / \mathrm{A}^{\mathrm{b}}$ & 38 \\
\hline In situ jet mixing and slurry reactor & 1 month & $\mathrm{N} / \mathrm{A}$ b & 46 \\
\hline $\begin{array}{l}\text { In situ electromagnetic or } \\
\text { radiofrequency energy heating }\end{array}$ & $\begin{array}{l}5 \text { months (3 mo. installation, } \\
2 \text { mo. operation) }\end{array}$ & $\begin{array}{l}20 \mathrm{cy} / \mathrm{d} \text { for demo } \\
200 \text { tons/d full scale }\end{array}$ \\
\hline In situ (ex situ) hydrogen peroxide & $\begin{array}{l}\text { Installation about } 1 \text { week, } \\
\text { operation about } 1 \text { month }\end{array}$ & $100 \mathrm{cy} / \mathrm{d}$ & 39 \\
\hline Ex situ thermal desorption & 5 months to 2 years & 100 to 200 tons/d full scale & 34 \\
\hline Ex situ immobilization & 1 months & 10,000 to $20,000 \mathrm{cf} / \mathrm{d}$ \\
\hline
\end{tabular}

a Score listed is the result from the ranking process. The higher the score the greater the ability of the technology to minimize full-scale remediation costs.

$b$ Not done to remove VOCs at the time of this demonstration. 


\section{APPENDIX D}

\section{REFERENCES}

1. Chemical Waste Management, Inc. 1992. Final project report for X-231B In Situ Stabilization Demonstration Project at the Portsmouth Gaseous Diffusion Plant, Piketon, Ohio. Prepared by Chemical Waste Management, Inc., Columbia, SC for Martin Marietta Energy Systems, Inc., Oak Ridge National Laboratory, Oak Ridge, TN, 37831

2. Advanced Sciences, Inc. 1988. Sampling Report for Piketon Oil Biodegradation Plot Project. ASI Project Number 661, Task 10. Prepared by Advanced Sciences, Inc. for Martin Marietta Energy Systems, Inc.

3. Morrison Knudsen Corporation. 1989. X-231B Oil Biodegradation Plot Closure Options Study, 1989. Report POEF-Z-4198. Prepared by Morrison Knudsen Corporation Environmental Services Group, Cleveland, Ohio for the Portsmouth Gaseous Diffusion Plant, operated by Martin Marietta Energy Services, Inc. for the U.S. Department of Energy.

4. Siegrist, R.L., Morris, M.I., Donaldson, T.L., Palumbo, A.V., Herbes, S.E., Jenkins, R.A., Morrissey, C.M., and Harris, M.T. 1993. The X-231B Technology Demonstration for In Situ Treatment of Contaminated Soils: Technology Evaluation and Screening. Oak Ridge National Laboratory Report, ORNL/TM-12257.

5. Davenport, D. T., D. J. Georgopoulos, R. L. Siegrist, M. I. Morris, and O. M. West. 1993. Technology Demonstration, Assessment, and Application for a RCRA Closure, Observations and Lessons Learned in the Process. Presented at WM93, February 28 - March 4, 1993, Tucson, AZ.

6. Morris, M. I., R. L. Siegrist, and D. T. Davenport. 1993. Environmental Technology Demonstrations at U. S. DOE Facilities: Observations Regarding the Current Process and Methods for Improvement. Presented at WM93, February 28 - March 4, 1993, Tucson, AZ.

7. Reyes, O. M., R. L. Siegrist, D. D. Gates, H. L. Jennings, A. J. Lucero, and R. A. Jenkins. 1992. Technical Workplan for ORNL Treatability Studies. Interim Report ERP-TI/91-628, Oak Ridge National Laboratory, Oak Ridge, TN.

8. U.S. Department of Energy. 1991. Environmental Assessment for the X-231B Soil Decontamination Technology Demonstration at the Portsmouth Gaseous Diffusion Plant, Piketon, Ohio. U.S. Department of Energy Report DOE/EA-0607.

9. Muhr, C.A., D.A. Pickering, R.L. Siegrist, T.J. Mitchell, R.A. Jenkins, and D.W. Greene. 1991. Technical Workplan for Sampling for Characterization and Treatability Studies. Internal report ERP-TI/91-627, Oak Ridge National Laboratory, Oak Ridge, TN, 37831.

10. Siegrist, R.L., M.I. Morris, D.A. Pickering, S.E. Herbes, O.M. Reyes, T.J. Mitchell, R.A. Jenkins, and C.A. Muhr. 1992. ORNL Technical Workplan for Field Demonstration, Testing, and Evaluation Studies. Internal report ERP-TI/92-223, Oak Ridge National Laboratory, Oak Ridge, TN, 37831.

11. West, O.R., Siegrist, R.L., Mitchell, T.J., Pickering, D.A., et al. 1993. The X-23IB Technology Demonstration for In Situ Treatment of Contaminated Soils: Contaminant Characterization and Three-Dimensional Spatial Modeling. Oak Ridge National Laboratory Report, ORNL/TM-12258.

12. Siegrist, R.L. et al. 1991. Project Description for In Situ Soil Mixing and Physicochemical Treatment Processes for Trichloroethylene and Other VOCs in Wet, Slowly Permeable Soils - Phase 2 Technology Demonstration. Oak Ridge National Laboratory, Oak Ridge, TN 37831.

13. West, O. R., R. L. Siegrist, J. S. Gierke, S. W. Schmunk, A. J. Lucero, and H. L. Jennings. 1995. "In Situ Mixed Region Vapor Stripping in Low Permeability Media. 1. Process Features and Laboratory Experiments." Environmental Science and Technology, 29(9):2191-2197.

14. Siegrist, R. L., O. R. West, M. I. Morris, D. A. Pickering, D. W. Greene, C. A. Muhr, D. T. Davenport, and J. S. Gierke. 1995. "In Situ Mixed Region Vapor Stripping in Low Permeability Media. 2. Full-Scale Field Experiments."

Environmental Science and Technology, 29(9):2198-2207. 


\section{APPENDIX D continued}

15. Gierke, J. S., C. Wang, O. R. West, and R. L. Siegrist. 1995. "In Situ Mixed Region Vapor Stripping in Low Permeability Media. 3. Modeling of Field Tests." Environmental Science and Technology, 29(9):2208-2216.

16. Geraghty \& Miller, Inc. 1989. Ground Water Quality Assessment of Four RCRA Units Portsmouth Gaseous Diffusion Plant, Piketon, Ohio. Prepared for the Portsmouth Gaseous Diffusion Plant, managed by Martin Marietta Energy Systems, Inc., for the U. S. Department of Energy.

17. -. 1990. International Waste Technologies/Geo-Con In Situ Stabilization/Solidification. EPA/540/A5-89/004.

18 Rust Geotech. 1995. Commercial Environmental Cleanup - The Products and Services Directory. DOE/ID/12584-230. GJPO-120.

19. Jolley, R.L., M.I. Morris, and S.P.N. Singh. 1991. Guidance Manual for Conducting Technology Demonstration Activities. Oak Ridge National Laboratory Report, ORNL/TM-11848. 